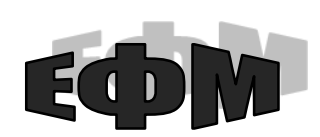

http://efm.vsau.org/

ФІНАНСОВО-КРЕДИТНЕ ЗАБЕЗПЕЧЕННЯ І ПОААТКОВА ПОЛІТИКА

УАК 657.6

\author{
АУАИТ У РЕАЛІЗАЦІЇ ІНТЕРЕСІВ \\ КОРИСТУВАЧІВ ФІНАНСОВОЇ \\ ІНФОРМАЦІї ${ }^{\odot}$
}

\author{
ШЕРСТЮК О.Л., \\ доктор економічних наук, доцент, \\ провідний науковий співробітник \\ відділу обліку та оподаткування \\ Національний науковий центр \\ "Інститут аграрної економіки» \\ Національної академії \\ аграрних наук України
}

(м. Kü̈в)

Досліджено особливості руху фінансової інформації між ії емітентами та користувачами. Ідентифіковано основні види змін, що відбуваються у фінансовій інформачії за результатами реалізачії управлінських рішень. Обтрунтовано необхідність та механізми забезпечення довіри до фінансової інформачії. Розроблено модель руху фінансової інформачії. Доведено наявність впливу думки аудитора щчодо фінансової інформачії та результатів ї̈ використання на поведінку емітента і користувача. Визначено, що наслідки такого впливу можуть змінюватися в діапазоні від беззастережного прийняття рімень на основі перевіреної фінансової інформації до такого ж беззастережного відкидання можливості ї̈ використання. Встановлено, щчо модифікація кола руху фінансової інформації залежить від фактів оцінювання результатів ї̈ застосування та застосування попередньої перевірки. Обгрунтовано наявність позитивного впливу розширення кола руху фінансової інформації на рівень довіри до неї користувача.

Ключові слова: Фінансова інформація, користувачі фінансової інформації, аудит, модель руху фінансової інформації, думка аудитора, модифікація кола руху фінансової інформації.

Рис.: 1. Літ.: 21.

\title{
AUDIT IN REALIZATION OF INTERESTS OF USERS OF FINANCIAL INFORMATION
}

SHERSTIUK Oleksandr,

Doctor of Economics, associate professor, leading researcher of the Accounting and Taxation Department of the National Scientific Center "Institute of Agrarian Economics" of the National Academy of Agrarian Sciences of Ukraine

(Kiev)

The features of the movement of financial information between its issuers and users are investigated. The main types of changes occurring in financial information based on the results of management decisions are identified. The necessity and mechanisms of providing confidence in financial information were substantiated. A model of financial information movement has been developed. The influence of the auditor's opinion on financial information and the results of its use on the behavior of the issuer and the user is proved. It was determined that the consequences of such effects may vary in the range of unconditional decision based on audited financial information to the same unconditional rejection of its use. It has been established that the modification of the circle of financial information depends on the facts of the evaluation of the results of its application and the use of the preliminary verification. The existence of the positive influence of the expansion of the financial information circulation circle on the level of trust to the user is substantiated.

Key words: Financial information, users of financial information, audit, model of motion of financial information, opinion of the auditor, modification of the circle of financial information movement.

Fig.: 1. Lit.: 21. 


\title{
АУДИТ В РЕАЛИЗАЦИИ ИНТЕРЕСОВ ПОЛЬЗОВАТЕЛЕЙ ФИНАНСОВОЙ ИНФОРМАЦИИ
}

\author{
ШЕРСТЮК Александр Леонидович, \\ доктор экономических наук, доцент, \\ ведущий научный сотрудник отдела учета и налогообложения \\ Национального научного центра «Институт аграрной экономики» \\ Национальной академии аграрных наук Украины
}

(2. Киев)

Исследованы особенности движения финансовой информации между ее эмитентами и пользователями. Идентифищированы основные виды изменений, происходящих в финансовой информации по результатам реализачии управленческих решений. Обоснованы необходимость и механизмы обеспечения доверия к финансовой информачии. Разработана модель движения финансовой информации. Доказано наличие влияния мнения аудитора о финансовой информации и результатах ее использования на поведение эмитента и пользователя. Определено, что последствия такого воздействия могут изменяться в диапазоне от безоговорочного принятия решений на основе проверенной финансовой информации до такого же безоговорочного отвержения возможности ее использования. Установлено, что модификация круга движения финансовой информаџии зависит от фактов оценки результатов ее применения и применения предварительной проверки. Обосновано наличие положительного влияния расширения круга движения финансовой информации на уровень доверия к ней пользователя.

Ключевые слова: Финансовая информация. Пользователи финансовой информации. Аудит. Модель движения финансовой информации. Мнение аудитора. Модификация круга движения финансовой информации.

Рис.: 1. Лит.: 21.

Постановка проблеми. 3 розвитком економічних відносин в Україні та світі має місце трансформація змісту і форм окремих процесів, змінюється роль їх учасників, уточнюються їх цілі і завдання, зазнають змін способи їх вирішення. Внаслідок цього, змінюється роль інформаційного забезпечення економічних процесів, що є наслідком змін в інформаційних потребах користувачів інформації, удосконаленням засобів іiі отримання, обробки та використання, перегляду ії якісних та кількісних характеристик, виходячи як з зацікавленості користувачів, так і з модифікації завдань, що можуть бути виконані за результатами ії використання.

Інформаційні потреби користувачів фінансової інформації можуть відрізнятися залежно від завдань, для вирішення яких планується застосування відповідної інформації, а також готовності користувача до сприйняття певного обсягу інформації, що може бути обумовлене його інтересами як суб'єкта економічних відносин, професійною підготовкою, ресурсним забезпеченням, а також суб'єктивним ставленням, власним розумінням своєї ролі у відносинах з емітентами фінансової інформації та іншими ії користувачами. Враховуючи, що інформація, в тому числі і фінансова, в умовах розвитку економічних відносин набуває ознак товару, а окремі категорії користувачів можуть розглядатися як його споживачі, можна припустити, що сукупність наведених чинників визначає зміст споживчої поведінки користувача фінансової інформації.

Зважаючи на це, виникає необхідність оцінювання споживчих характеристик фінансової інформації, за результатами якого користувачі отримають упевненість в можливості іiі використання для досягнення власних цілей.

Одним 3 механізмів такого оцінювання є аудит. Саме результати аудиторської перевірки інформації, зокрема фінансової, дають можливість користувачам упевнитися в іії відповідності низці критеріїв якісного, кількісного та вартісного змісту.

Водночас, думка, що іï висловлює аудитор за наслідками своєї роботи, має суб'єктивну природу. Наслідком цього може бути різноманітність тлумачень характеристик окремих показників та їх сукупності різними виконавцями завдань аудиту. Зазначену проблему, на наше переконання, можна вирішити через визначення загального розуміння ролі аудиту в інформаційному забезпеченні функціонування суб'єктів господарювання та осіб, зацікавлених у відповідній інформації про господарську діяльність та її результати. Вважаємо, що вирішенню цієї проблеми сприятиме, серед іншого, максимальне врахування в роботі аудитора потреб користувачів фінансової інформації. 


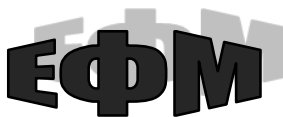

http://efm.vsau.org/

Таким чином, обумовлюється актуальність проведеного наукового дослідження, результати якого викладені у цій статті.

Аналіз останніх досліджень і публікацій. Аспекти використання фінансової інформації різного виду досліджуються у наукових публікаціях вітчизняних та закордонних авторів. При цьому, власне термін «користувач», визначений у Міжнародних стандартах контролю якості, аудиту, огляду, іншого надання упевненості та супутніх послуг, згідно з якими «користувачі особа, особи або категорія осіб, для яких фахівець-практик складає звіт із надання упевненості. Відповідальна сторона може виступати одним з визначених користувачів, але не єдиним» [1]. Зазначене визначення наведене, виходячи зі змісту аудиту фінансової звітності як завдання 3 надання упевненості. Такий підхід, на наше переконання, не враховує інтереси користувача, його обізнаність щодо змісту та характеристик самої інформації.

Підходи щодо вирішення проблем реалізації потреб користувачів фінансової інформації знайшли відображення у наукових публікаціях низки таких вітчизняних та закордонних дослідників як К. Загер, Л. Загер [2], І.В. Замула [3], С.В. Бардаш [4], О.В. Будько [5], Н.О. Бурбело [6], О.М. Дериколенко [7], Т. Дзюба [8], У. Шарп [9], П. Етрілл [10] та ін.

Серед інформаційних потреб користувачів у наведених та інших публікаціях виділяють дані про вартість активів, зобов'язань, величину власного капіталу, доходів і витрат, а також показники, які отримані не безпосередньо з форм звітності, а шляхом їх обробки та проведення відповідних розрахунків. Зазначений підхід, на нашу думку, не є достатньо обгрунтованим. 3 одного боку, за формальними ознаками отримані таким чином показники вже не мають грошового вимірника, тому не можуть бути визнані як фінансова інформація. 3 точки зору перспектив використання наведених даних для прийняття рішень, вони є похідними від даних, які безпосередньо включені до складу фінансової інформації.

Варто відзначити, що в наукових публікаціях інформаційні потреби користувачів ідентифікуються з урахуванням різних аспектів. Зокрема, досліджуються питання, пов'язані 3 визначенням змісту інформаційних потреб для цілей управління підприємством [11], його економічною та фінансовою безпекою [12], оцінки та контролю бізнес-процесів та реалізації маркетингової стратегії [13]. На нашу думку, варто звернути увагу на відсутність у відповідних публікаціях аналізу обставин, які обумовлюють доцільність реалізації зазначених цілей та запропонованих авторами методик, від чого залежить як адекватність вибору на основі інформації управлінських рішень, так й результат їх впровадження. Зокрема, це стосується механізму підвищення довіри до інформації, у тому числі - на основі використання результатів аудиту.

Проблеми трансформації аудиту, зокрема в контексті розвитку систем управління діяльністю економічних суб'єктів, розкриваються в наукових публікаціях таких дослідників, як В.П. Бондар [14], I.М. Дмитренко [15], Н.I. Дорош [16], О.Е. Лубенченко [17], О.А. Петрик [18], Н.М. Проскуріна [19], О.Ю. Редько [20], В.В. Рядська [21] та ін.

Водночас, вважаємо за доцільне констатувати, що в наукових публікаціях зазначених та інших дослідників і практикуючих фахівців приділено недостатньо уваги вирішенню проблем оптимізації інформаційного забезпечення рішень суб'єктів управління діяльністю підприємств із застосуванням можливостей аудиту.

Формулювання мети статті. Зважаючи на викладене, метою статті визначається ідентифікація ролі аудиту у формуванні інформаційного забезпечення діяльності підприємств.

\section{Виклад основного матеріалу дослідження.}

Інформація формується ії емітентом, виходячи з їі змісту та обставин, що визначають характер відповідних заходів. При цьому, підготовлена інформація може бути подана безпосередньо користувачам або передана для оцінювання спеціально підготовленій особі (аудитору) для отримання певного рівня упевненості щодо ії відповідності визначеному набору критеріїв.

Емітент та користувач інформації $є$ суб'єктами, наявність яких $є$ обов'язковою для ідентифікації іiі руху. Тому, рух інформації між зазначеними суб'єктами може бути визначений як рух в основному колі, яке не передбачає існування впливу інших осіб, що прямо чи опосередковано можуть надати інформації нових характеристик. Безпосереднє подання фінансової інформації від емітента користувачеві може бути визначене як іiї прямий рух.

Подання інформації користувачеві є одним з елементів інформаційного забезпечення заходів формування, обгрунтування та реалізації його рішень. Зважаючи на це, користувач визначає можливості використання отриманих даних в контексті досягнення власних цілей, зміст яких визначається 3 урахуванням різноманітних аспектів діяльності та впливу низки чинників суб'єктивного та об'єктивного характеру. 
Реалізація управлінських рішень, на наше переконання, може призвести до змін в об'єктах, які характеризуються, зокрема, фінансовою інформацією. Для ідентифікації таких змін вважаємо за доцільне визнати наявність декількох їх видів:

1) зміни, що відбуваються у кількісних характеристиках об’єктів. Зазначені зміни, на нашу думку, можуть стати наслідком виникнення обставин для ідентифікації нових фізичних одиниць об'єктів або припиненням існування таких обставин для вже існуючих об'єктів;

2) зміни, що відбуваються у вартісних характеристиках об'єктів. На нашу думку, вони можуть бути наслідком зміни обставин, пов'язаних з визначенням вартісної величини окремих фізичних одиниць об'єктів таһабо їх групи;

3) комбіновані зміни, причинами яких ми вважаємо одночасні зміни обставин, що призводять до необхідності перегляду як кількісних, так і вартісних характеристик об'єктів.

Таким чином, зміни в об'єктах, які характеризуються фінансовою інформацією, у власну чергу, мають бути ідентифіковані та оцінені з точки зору доцільності та способів врахування емітентом в подальшому. Така доцільність обумовлює актуалізацію інформації, виходячи зі змісту, характеру та величини змін, що відбуваються у відповідних об'єктах внаслідок прийняття та реалізації рішень користувача. Зміст відповідної актуалізації полягає у визначенні та застосуванні сукупності заходів, пов'язаних з формуванням нової фінансової інформації емітентом, які б дали можливість адекватно визначити, оцінити та розкрити зміни, що відбулися в об'єктах. Заходи актуалізації фінансової інформації передбачають врахування змін в об'єктах, що нею характеризуються, через переміщення в бік емітента, що дозволяє визначити такий рух як зворотній.

Однією з передумов застосування фінансової інформації в інтересах користувачів $є$ довіра до неї. Від рівня довіри до фінансової інформації залежить сама можливість ії використання для досягнення певних цілей. Проте, формування фінансової інформації здійснюється, як правило, на основі суб'єктивних припущень емітента щодо ідентифікації, оцінювання та розкриття змісту об'єктів. Суб'єктивна природа таких припущень дає підстави для визнання різних підходів та критеріїв, що застосовуються емітентами під час підготовки подібної інформації в різні проміжки часу. Водночас, суб' єктивність розуміння змісту інформації є властивою не лише для емітента, але й для користувача. 3 іншого боку, завжди існує імовірність протиріч в інтересах емітентів та користувачів фінансової інформації внаслідок впливу особистісних, нормативних, організаційних та інших обставин, що може призвести до навмисного чи помилкового внесення неточностей під час формування відповідних даних.

Зважаючи на це, рівень довіри до фінансової інформації з боку іiі користувачів коливатиметься залежно від їх суб'єктивних оцінок як самої інформації, так і механізмів їх формування. Тому, її використання для досягнення певних цілей супроводжуватиметься ризиками, пов'язаними з впливом наведених та інших чинників.

Одним з механізмів зменшення чи нейтралізації ризиків, пов'язаних з використанням фінансової інформації, є делегування незалежній особі, якою є аудитор, права на здійснення оцінювання як самої фінансової інформації, так і заходів, що супроводжують процеси іiі підготовки та подання користувачам. Для визначення ролі аудиту фінансової інформації в реалізації охарактеризованих процесів в контексті реалізації цілей осіб, які беруть участь у їі формуванні, оцінюванні та використанні, нами запропонована модель руху фінансової інформації, наведена на рис. 1.

Наведена на рис. 1 модель руху фінансової інформації дає можливість охарактеризувати роль iii аудиту в контексті застосування в інтересах користувачів.

Так, коло руху фінансової інформації розширюється за рахунок включення до нього додаткової особи. При цьому, сама інформація та результати її застосування зазнають оціночного, але не змістовного впливу з боку аудитора. Зважаючи на це, інформація внаслідок дослідження аудитором, не зазнаючи жодних змін, пов'язаних з відображенням певних об'єктів, набуває додаткової характеристики оціночного змісту. 3 точки зору аудитора як особи, що планує, виконує та оцінює результати заходів аудиту, така характеристика має суб'єктивний характер. Проте, беручи до уваги факт того, що безпосередньо аудитор не вживає жодних заходів щодо змін у змісті інформації, його оцінка з точки зору як користувача, так і емітента є об'єктивною.

На підставі зазначеного можна зробити висновок, що думка аудитора щодо фінансової інформації та/або результатів іiї використання доповнює іiї характеристики, що можуть вплинути як на поведінку емітента, так і на поведінку користувача.

Наявність такого впливу пояснюється саме рівнем довіри, який формується щодо інформації 3 урахуванням результатів іiі дослідження аудитором. Причому, наслідки такого впливу, як свідчать результати проведеного дослідження, можуть змінюватися від беззастережного прийняття рішень на основі перевіреної фінансової інформації до такого ж беззастережного відкидання можливості ії використання. 


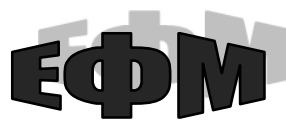

http://efm.vsau.org/

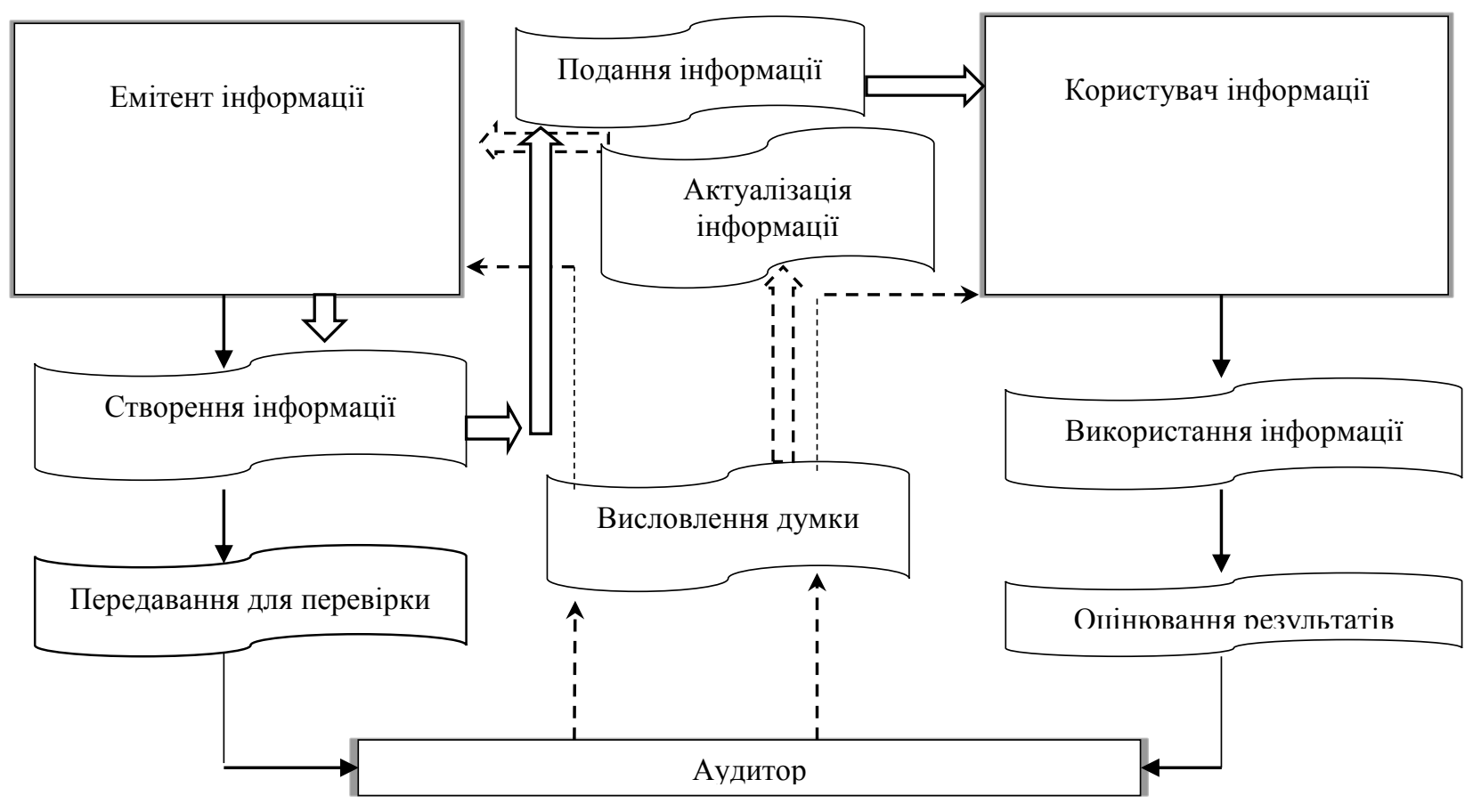

Рух інформачії в основному колі:
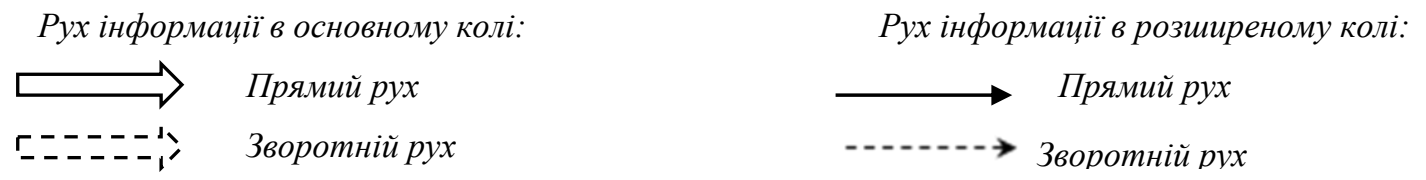

Рис. 1. Модель руху фінансової інформації

Джерело: авторська розробка

В разі залучення до руху фінансової інформації заходів ії перевірки та оцінювання аудитором, $є$ підстави визнати наявність розширеного кола iї руху.

При цьому, величина такого розширення в інтересах користувачів, на наше переконання, може мати три модифікації:

1) без оцінювання результатів застосування;

2) з урахуванням оцінювання результатів застосування без попередньої перевірки;

3) з урахуванням попередньої перевірки та результатів застосування.

Розширення кола руху фінансової інформації з урахуванням її перевірки передбачає передачу відповідних даних для дослідження аудитору з подальшим поверненням емітенту. Такий рух фінансової інформації може бути ідентифікований як прямий, оскільки вона надається для реалізації завдань аудиту. Натомість, повернення оціненої аудитором інформації емітенту має ознаки зворотного руху, оскільки пов'язане з одержанням результатів перевірки, формалізованих в аудиторському звіті.

Зважаючи на вимоги нормативно-правових документів, а також на інтереси користувачів фінансової інформації, основні їі носії доповнюються аудиторським звітом, в якому формалізується думка аудитора за результатом виконання відповідних заходів. Саме професійна думка аудитора і $є$ джерелом довіри до фінансової інформації з боку користувачів. Тому, для забезпечення іії належного рівня емітент подає користувачеві разом з носіями фінансової інформації аудиторський звіт.

Слід звернути увагу на те, що аудиторський звіт, який є способом формалізації результатів аудиту, серед іншого, містить інформацію про визнання аудитором відповідальності за результати своєї роботи. Іншими словами, користувач формально на основі аудиторського звіту розподіляє ризики, по’вязані з використанням перевіреної фінансової інформації.

Зазначене дає можливість зробити висновок про наявність позитивного впливу розширення кола руху фінансової інформації на рівень довіри до неї користувача.

Водночас, у випадку наявності високого рівня узгодженості інтересів емітента та користувача фінансової інформації проведення іiі аудиту позитивно впливатиме і на оцінку роботи емітента. Адекватна оцінка заходів, що супроводжують формування фінансової інформації та ії подання користувачам, на нашу думку, сприятиме розумінню відповідних процесів, зокрема - ефективності 
функціонування системи внутрішнього контролю, яке здатне не лише забезпечити користувачів необхідною інформацією, але й сприятиме вирішенню завдань, пов'язаних зі збереженням активів, підвищенню ефективності функціонування емітента та оптимізації його організаційної й функціональної структури.

Розширення кола руху фінансової інформації з урахуванням оцінювання результатів іiі застосування в інтересах користувачів передбачає виконання аудитором заходів, спрямованих на оцінювання змін, які відбулися внаслідок прийняття рішень на основі отриманої від емітента фінансової інформації. Результати таких рішень також узагальнюються у вигляді інформації, яка, в подальшому, може вплинути на процеси формування нових даних шляхом актуалізації попередніх.

В контексті надання аудитору результатів застосування фінансової інформації для оцінювання, іiі рух від користувача до аудитора може бути визначений як прямий. Це пояснюється тим, що таке надання передбачає необхідність виконання аудитором певної сукупності заходів, спрямованих на визначення відповідності даних визначеному набору критеріїв. Натомість, формалізована в аудиторському звіті думка аудитора щодо результатів використання інформації, що містить упевненість щодо стану досягнення визначених користувачем цілей, надається користувачу інформації разом з поверненням даних, наданих аудитору для оцінювання, що має ознаки зворотного руху.

Будь-яка реалізація інтересів користувачів на основі використання фінансової інформації спричиняє зміну характеристик об'єктів, які в цій інформації були охарактеризовані. Таким чином, результатом заходів, що виконуються аудитором в цілях оцінювання наслідків використання інформації, є визначення ступеня відповідності отриманих змінених характеристик об'єктів очікуванням користувачів.

Водночас, зміни в якісних та кількісних характеристиках об'єктів потребують врахування під час актуалізації інформації емітентом, що обумовлює необхідність врахування оціночної думки аудитора на етапі підготовки інформації, що стосується наступних періодів. Зважаючи на це, можна зробити висновок про важливість розширення кола руху фінансової інформації за рахунок аудиторського оцінювання результатів іiі використання як в контексті реалізації інтересів користувачів, так і для належного обгрунтування заходів, що виконуються емітентами.

Ще однією модифікацією кола руху фінансової інформації є його розширення з одночасним урахуванням перевірки даних, що стосуються самої інформації та результатів ії використання.

В даному випадку існуватиме можливість забезпечення аудиторського супроводження руху інформації, починаючи від іiі підготовки і завершуючи іiї актуалізацією. При цьому, в інтересах користувачів фінансової інформації аудитор надаватиме оціночні характеристики як інформаційному забезпеченню, так й результатам діяльності користувача. Натомість, висловлення думки щодо підстав та оцінок впливу чинників актуалізації інформації сприятиме оптимізації заходів, що виконуються їі емітентами на етапі формування, а перевірка сформованих даних надасть можливість адекватно оцінити результати таких заходів.

Висновки. Таким чином, проведене дослідження сприяло ідентифікації ролі аудиту у формуванні інформаційного забезпечення діяльності підприємств. Зокрема, отримані результати свідчать про потребу в перегляді змісту аудиту з урахуванням необхідності дослідження фінансової інформації. Власне аудит можна розглядати як невід'ємну ланку оптимального руху фінансової інформації. Використання результатів аудиту для підвищення надійності інформації, на наше переконання, сприятиме підвищенню адекватності рішень, що формуватимуться на їі основі.

При цьому, зважаючи на суб'єктивний характер професійної думки аудиторів, що висловлюється за результатами проведеної ними роботи, обгрунтовує необхідність подальших досліджень, результатом яких, як очікується, стане удосконалення організаційних та методичних підходів, що застосовуються для її формування.

\section{Список використаних джерел:}

1. Handbook of International Quality Control, Auditing, Review, Other Assurance, and Related Services Pronouncements. URL: http://www.ifac.org/publications-resources/2018-handbookinternational-quality-control-auditing-review-other-assurance (дата звернення: 17.05.2019).

2. Zager K., Zager L. The role of financial information in decision making process. Innovative Marketing. 2006. Vol. 2. Issue 3. Pp. 35-40.

3. Аналітична оцінка та контроль бізнес-процесів в межах маркетингової стратегії суб'єкта господарювання: монографія / за заг. ред. Замули І. В. Житомир: Видавець О. О. Свенок, 2016. 388 с.

4. Бардаш С. В. Захист інтересів користувачів фінансової звітності: стан та підходи до гарантування. Науковий вісник Національної академії статистики, обліку та аудиту. 2013. Вип. № 2. C. 20-27. 


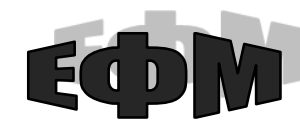

http://efm.vsau.org/

5. Будько О. В. Фінансова звітність як джерело інформації для прийняття управлінських рішень. Ефективна економіка. 2013. № 1. URL: http://www.economy.nayka.com.ua/?op=1\&z=1721 (дата звернення: 01.12.2017).

6. Бурбело Н. О. Формування комплексу заходів антикризового управління підприємством. Інноваиійна економіка. 2017. № 1-2 (67). С. 65-70.

7. Дериколенко О. М. Теоретико-методологічні засади венчурної діяльності промислових підприємств : дис. ... д-ра екон. наук : 08.00.04 / Сумський державний університет. Суми, 2017. 516 с.

8. Дзюба Т. Обліково-інформаційне забезпечення управління економічною потужністю: аналітичний аспект. Формування ринкової економіки в Україні. 2017. Вип. 37. Ч. 1. С. 158-162.

9. Шарп У. Инвестиции / пер. с англ. Буренина А. Н., Васина А.А. Москва : Инфра-М, 1997. 1024 с.

10. Этрилл П. Четыре шага подготовки финансовых прогнозов. URL http://www.elitarium.ru/finansovyje_prognozy/ (дата звернення: 09.05.2019).

11. Ковач С. І. Концепція суттєвості в обліку і звітності. Бізнес Інформ. 2014. № 6. С. 284-288.

12. Коваленко О. В., Болдуєв I. С. Про формування системи економічної безпеки підприємства. Економічний вісник університету. 2017. Вип. 30/1. С. 63-69.

13. Інновації у маркетингу і менеджменті: монографія / за заг. ред. С. М. Ілляшенка. Суми: TOB «Друкарський дім «Папірус», 2013. 616 с.

14. Бондар В. П. Концепція розвитку аудиту в Україні: теорія, методологія, організація : монографія. Житомир : Житомирський державний технологічний університет, 2008. 456 с.

15. Дмитренко I. М. Концепція розвитку аудиту корпоративних систем : монографія. Київ : Кондор-Видавництво, 2013. 364 с.

16. Дорош Н. І. Аудит: теорія і практика : монографія. Київ : Знання, 2006. 495 с.

17. Лубенченко О. Е. Роль зовнішнього аудиту в залученні іноземних інвестицій та виході вітчизняних компаній на ринок IPO. Бізнес Інформ. 2016. №1. С. 89-94.

18. Петрик О. А. Стан та перспективи розвитку аудиту в Україні: методологічні та організаційні аспекти : автореф. дис. на здобуття наук. ступеня д-ра екон. наук : 08.06 .04 / Київський національний економічний університет. Київ, 2004. 34 с.

19. Проскуріна Н. М. Розвиток процедур аудиту: теорія та методологія : автореф. дис. на здобуття наук. ступеня д-ра екон. наук : 08.00.09. Київ, 2012. 38 с.

20. Редько О. Ю. Аудит в Україні. Морфологія : монографія. Київ : ДП "Інформ.-аналіт. агентство", 2008. 493 с.

21. Рядська В. В. Аудит в економічній системі України: сучасний стан та концепція розвитку: монографія. Чернігів : Видавець Лозовий В.М., 2014. 472 с.

\section{References:}

1. Handbook of International Quality Control, Auditing, Review, Other Assurance, and Related Services Pronouncements. Retrieved from: http://www.ifac.org/publications-resources/2018-handbookinternational-quality-control-auditing-review-other-assurance (17.05.2019) [In English].

2. Zager, K., Zager, L. The role of financial information in decision making process. Innovative Marketing. 2006. Vol. 2. Issue 3. Pp. 35-40 [In English].

3. Zamula, I.V. (2016). Analitychna otsinka ta kontrol biznes-protsesiv v mezhakh marketynhovoi stratehii subiekta hospodariuvannia: monohrafiia [Analytical assessment and control of business processes within the marketing strategy of a business entity: a monograph]. Zhytomyr: O. O. Yevenok [In Ukrainian].

4. Bardash, S.V. (2013). Zakhyst interesiv korystuvachiv finansovoi zvitnosti: stan ta pidkhody do harantuvannia [Protecting the interests of users of financial reporting: the state and approaches to guarantee]. Naukovyi visnyk Natsionalnoi akademii statystyky, obliku ta audytu - Scientific Journal of the National Academy of Statistics, Accounting and Audit, 2, 20-27 [In Ukrainian].

5. Budko, O.V. (2013). Finansova zvitnist yak dzherelo informatsii dlia pryiniattia upravlinskykh rishen [Financial reporting as a source of information for making managerial decisions]. Efektyvna ekonomika [Effective economics], $1 . \quad$ Retrieved from: http://www.economy.nayka.com.ua/?op=1\&z=1721 (01.12.2017) [In Ukrainian].

6. Burbelo, N.O. (2017). Formuvannia kompleksu zakhodiv antykryzovoho upravlinnia pidpryiemstvom [Formation of the complex of measures of crisis management of the enterprise]. Innovatsiina ekonomika - Innovative economics, 1-2 (67), 65-70 [In Ukrainian].

7. Derykolenko, O.M. (2017). Teoretyko-metodolohichni zasady venchurnoi diialnosti promyslovykh pidpryiemstv [Theoretical and methodological principles of venture capital of industrial enterprises]. Doctor's thesis. Sumy: SumDU [In Ukrainian]. 
8. Dziuba, T. (2017). Oblikovo-informatsiine zabezpechennia upravlinnia ekonomichnoiu potuzhnistiu: analitychnyi aspect [Accounting and information support of management of economic power: analytical aspect]. Formuvannia rynkovoi ekonomiky v Ukraini - Formation of a market economy in Ukraine, 37, 158-162 [In Ukrainian].

9. Sharp, U. (1997). Ynvestytsyy [Investments]. Moscow: Ynfra-M [In Russian].

10. Etryll, P. Chetyre shaha podhotovky fynansovykh prohnozov [The Four Steps To Preparing Financial Forecasts]. Retrieved from: http://www.elitarium.ru/finansovyje_prognozynia (09.05.2019) [In Russian].

11. Kovach, S.I. (2014). Kontseptsiia suttievosti v obliku i zvitnosti [Concept of materiality in accounting and reporting]. Biznes Inform - Business Inform, 6, 284-288 [In Ukrainian].

12. Kovalenko, O.V., Bolduiev, I.S. (2017). Pro formuvannia systemy ekonomichnoi bezpeky pidpryiemstva [About the formation of the system of economic security of the enterprise]. Ekonomichnyi visnyk Universytetu - Economic Herald of the University, 30/1, 63-69 [In Ukrainian].

13. Illiashenko, S.M. (2013). Innovatsii u marketynhu i menedzhmenti: monohrafiia [Marketing and management innovations: monograph]. Sumy: TOV «Drukarskyi dim «Papirus» [In Ukrainian].

14. Bondar, V.P. (2008). Kontseptsiia rozvytku audytu v Ukraini: teoriia, metodolohiia, orhanizatsiia : monohrafiia [The Concept of Audit Development in Ukraine: Theory, Methodology, Organization: Monograph]. Zhytomyr : Zhytomyrskyi derzhavnyi tekhnolohichnyi universytet [In Ukrainian].

15. Dmytrenko, I.M. (2013). Kontseptsiia rozvytku audytu korporatyvnykh system : monohrafiia [Concept of development of audit of corporate systems: a monograph]. Kyiv : Kondor-Vydavnytstvo [In Ukrainian].

16. Dorosh, N.I. (2006). Audyt: teoriia i praktyka : monohrafiia [Audit: theory and practice: monograph]. Kyiv : Znannia [In Ukrainian].

17. Lubenchenko, O.E. (2016). Rol zovnishnoho audytu v zaluchenni inozemnykh investytsii ta vykhodi vitchyznianykh kompanii na rynok IPO [The role of external audit in attracting foreign investments and the exit of domestic companies into the market of IPO]. Biznes Inform - Business Inform, 1, 89-94 [In Ukrainian].

18. Petryk, O.A. (2004). Stan ta perspektyvy rozvytku audytu v Ukraini: metodolohichni ta orhanizatsiini aspekty [The state and prospects of audit development in Ukraine: methodological and organizational aspects: author's abstract. dis for the sciences]. Extended abstract of Doctor's thesis. Kyiv, Kyivskyi natsionalnyi ekonomichnyi universytet [In Ukrainian].

19. Proskurina, N.M. (2012). Rozvytok protsedur audytu: teoriia ta metodolohiia [Development of audit procedures: theory and methodology: author's abstract. dis for the sciences]. Extended abstract of Doctor's thesis. Kyiv [In Ukrainian].

20. Redko, O.Yu. Audyt v Ukraini. Morfolohiia : monohrafiia [Audit in Ukraine. Morphology: Monograph]. Kyiv : DP "Inform.-analit. ahentstvo" [In Ukrainian].

21. Riadska, V.V. (2014). Audyt v ekonomichnii systemi Ukrainy: suchasnyi stan ta kontseptsiia rozvytku : monohrafiia [Audit in the economic system of Ukraine: the current state and concept of development: a monograph]. Chernihiv : Vydavets Lozovyi V.M. [In Ukrainian].

\section{Інформація про автора:}

ШЕРСТЮК Олександр Леонідович - доктор економічних наук, доцент, провідний науковий співробітник відділу обліку та оподаткування Національного наукового центру «Інститут аграрної економіки» Національної академії аграрних наук України (03127, Україна, м. Київ, вулиця Героїв Оборони, буд. 10)

SHERSTIUK Oleksandr - Doctor of Economics, associate professor, leading researcher of the Accounting and Taxation Department of the National Scientific Center "Institute of Agrarian Economics" of the National Academy of Agrarian Sciences of Ukraine (03127, Ukraine, Kiev, Heroes of Defense street, 10)

Шерстюк Александр Леонидович - доктор экономических наук, доцент, ведущий научный сотрудник отдела учета и налогообложения Национального научного центра «Институт аграрной экономики» Национальной академии аграрных наук Украины (03127, Украина, г. Киев, улица Героев Обороны, д. 10)

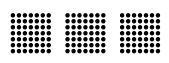

